Language in Africa 1(3), 2020, 100-124. doi: 10.37892/2686-8946-2020-1-3-100-124

\title{
THE INTERNAL RECONSTRUCTION OF BENA-YUNGUR CONSONANTS AND TONE PATTERNS
}

\author{
Dmitry Idiatov \\ LLACAN (CNRS - INALCO) \\ dmitry.idiatov@cnrs.fr \\ Mark L.O. Van de Velde \\ LLACAN (CNRS - INALCO) \\ mark.vandevelde@cnrs.fr
}

Abstract: This paper provides proposals for the internal reconstruction of BenaYungur [Glottocode: bena1260]. The present-day three-tone system of Bena-Yungur with an opposition between $H, M$ and $L$ must result from a relatively recent process of tonogenesis in which $L$ tones were reinterpreted as $M$ whenever they were not realised extra low due to a preceding voiced stop that acted as a depressor consonant. Although subsequent changes have somewhat blurred the correlation between tones and segments, this correlation still proves highly relevant for the internal reconstruction of the laryngeal settings of stem-initial consonants. We also show that the contemporary Bena-Yungur lexical tone patterns are the result of the neutralisation of a higher number of previously existing patterns due to the application of tone rules. The former distinctions between different tone patterns are still observable in the genitive construction for nouns and in positive perfective forms and product nominalisations for verbs. This allows us to reconstruct the original tone patterns of nouns and verbs, as well as aspects of the genitive construction and perfective verb forms. Remarkably, the tonal reconstruction makes it clear that the direction of tonal interactions must have shifted from anticipatory to perseveratory in the history of Bena-Yungur.

Key words: internal reconstruction, tone, tonogenesis, depressor consonants, direction of assimilation, laryngeal settings 


\section{Introduction}

This paper provides some proposals for the internal reconstruction of Bena-Yungur [Glottocode: bena1260]. It builds on our description of the tone system published as Idiatov \& Van de Velde (2018), the main findings of which will be summarised and at some places elaborated in $\S 2$. Bena-Yungur is one of the Bena-Mboi languages, which are traditionally classified as a subgroup of Adamawa, but whose genealogical classification is still disputed (Kleinewillinghöfer 1996a; 1996b; Idiatov \& Van de Velde 2019). In $§ 3$ we will show how tone is relevant for the internal reconstruction of segmental phonology, and more precisely of the laryngeal settings of stem-initial consonants. §4 is dedicated to nouns. Thanks to the existence of Dependent Tone Schemes that preserve tonal oppositions that have been neutralised elsewhere, we can reconstruct the tone patterns of nouns. At the same time, we gain insight in the historical development of tone rules in Bena-Yungur, which must have changed in nature from anticipatory to perseveratory. Dependent Tone Schemes also give indications for the reconstruction of aspects of a genitive construction, of which all formal marking has now disappeared. In $\S 5$, finally, we reconstruct the tone patterns of verbs, as well as aspects of the Positive Perfective conjugation and product nominalisations. Where relevant and possible, we will adduce new external evidence from the ongoing documentation of the related languages Laala-Roba [Glottocode: lala1261] and Mboi [Glottocode: mboi1246].

\section{The Bena-Yungur tone system}

Bena-Yungur has three level tones - H(igh), M(id) and L(ow) which can combine to form almost every logically possible two-tone contour on a syllable, the tone bearing unit (TBU): falling (HM, HL) or rising (LM, LH, MH). ${ }^{1}$ Only one three-tone contour is allowed:

${ }^{1}$ Unless explicitly stated otherwise, the Bena-Yungur data discussed in this paper represents the Pra (Párá) dialect, our reference variety of Bena-Yungur. 
HLH. There is no downstep. Bena-Yungur has floating tones of the three tone levels, here symbolised by superscript letters: ${ }^{\mathrm{H}},{ }^{\mathrm{M}}$ and ${ }^{\mathrm{L}}$. There are no sequences of floating tones. When a morphological process results in the creation of a sequence of two floating tones, the second one is deleted. Floating tones can result from the application of a tone rule or they can be specified in the lexicon. Our data contains only one lexical item with an (optional) floating tone, the word àtwán ${ }^{(H)}$ 'grasshopper (sp.)'. All other lexically specified floating tones are part of function words, such as $\bar{\partial} n^{H}$ 'with', $m b a ́ k \bar{a}^{H}$ 'something', $\grave{a}^{M}$ 'on, at', áy $y^{L}$ '3sG.An.be' and $w u^{L}$ '3.InAn.be'. Two tone rules are active in the language: tone spread and tonal absorption.

Tone spread is the rule by which every tone can and normally does spread one position to the right across a word boundary. $\mathrm{H}$ tones can always spread to the right, as illustrated in (1) and (2), as well as below in (4) and (5).
(1) tó: \# gbèsê $\rightarrow$ tó: gbêsê
'Take the calabash spoon!'
(2) tó: \# bōllā $\rightarrow$ tó: bóllā
'Take the pumpkin!'

In contrast, there are two types of restrictions on the spreading of $\mathrm{L}$ and $\mathrm{M}$ tones. First, they can only spread when the following tone is $\mathrm{H}$. In other words, a $\mathrm{L}$ never spreads onto a $\mathrm{M}$ and a $\mathrm{M}$ never on a $\mathrm{L}$, as illustrated in (3) and (4).
(3) dàr \# bōllā
$\rightarrow$ dà: 6ōllā
'Touch the pumpkin!'
(4) rō: \# bàreñn \# yā
$\rightarrow$ rō: bà̀rén yā
'Pinch this liar!'

Second, they can only spread on a following $\mathrm{H}$ if that $\mathrm{H}$ is followed by a pause or by another $\mathrm{H}$, as illustrated in (5) vs. (6). We will come back to tone spread in $\S 3$.
(5) jāa: \# dálmáttà
$\rightarrow \quad$ nā: đālmáttà
'This is a stutterer.'
(6) nāa: \# rấddà
$\rightarrow \quad$ nā: rấddà
'This is a catfish.' 
The rule of tonal absorption stipulates that the final part of a contour tone is deleted when followed by an identical tone, for instance HM > $\mathrm{H} / \ldots \mathrm{M}$ as on the second syllable of bàreen in (4). When they are separated from each other by a word boundary, L and M tones tend to behave as if they were identical in the application of the tone absorption rule too, as in (7) where $\mathrm{HL}>\mathrm{H} /$ _ \#M vs. (8) where HL remains $\mathrm{HL}$ before $\mathrm{M}$ within the same word.

(7) tó: \# gbèsê \# yā $\rightarrow$ tó: gbêsé yā (8) tó: \# gòndō $\rightarrow$ tó: gôndō

'Take this calabash spoon!' 'Take the snail!'

As we have argued in Idiatov \& Van de Velde (2018), the distribution of tones in lexemes shows that the current three-way tonal distinction must be the result of a relatively recent process of tonogenesis (see Michaud \& Sands 2020 for a recent overview of tonogenesis). First, about half of the monosyllabic nouns and verbs have a $\mathrm{H}$ tone, whereas $\mathrm{M}$ and $\mathrm{L}$ tones occur in about a quarter of the monosyllabic stems each. Together with the fact already mentioned that $\mathrm{L}$ and $\mathrm{M}$ tones behave as if they were one and the same in the application of tone rules, this suggests that the distinction between $\mathrm{L}$ and $\mathrm{M}$ is the result of the split of a proto ${ }^{*} \mathrm{~L}$ that previously only contrasted with a $* \mathrm{H}$. Second, there is a very strong correlation between the tone of stem-initial syllables and the nature of their onset consonant. With very few exceptions - mostly found in borrowings, words for animals and plants, some ideophones and functional words - stem-initial syllables whose onset is a voiced stop $/ \mathrm{b}, \mathrm{d}, \mathrm{g}, \mathrm{gb} /$ have a $\mathrm{L}$ tone, while voiceless and implosive stops /p, t, tf, $\mathrm{k}, \mathrm{kp}, \mathrm{b}, \mathrm{d} /$, the voiceless fricative $/ \mathrm{S} /$ and the voiceless glottal continuant $/ \mathrm{h} /$ are followed by either a $\mathrm{M}$ or a $\mathrm{H}$. Non-velar nasals $/ \mathrm{m}, \mathrm{n}, \mathrm{n} /$, as well as the nasalinitial clusters with a non-velar stop $/ \mathrm{mb}, \mathrm{nd} /$, and non-velar continuants $/ \mathrm{r}, 1, \mathrm{y} /$ similarly pattern with voiceless and implosive stops. There is no clear pattern for the voiceless fricatives $/ \mathrm{s} /$ and $/ \mathrm{f} /$, the labial-velar approximants $/ \mathrm{w} /$ and $/ \tilde{\mathrm{w}} /$, nor for the nasal-initial clusters with a velar and labial-velar stop $/ \mathrm{gg}, \widehat{\mathrm{jm}} \widehat{\mathrm{gb}} /$. Consonant clusters with a labial-velar 
approximant as the final element, such as /bw, mbw, mw̃, gw, ggw, $\mathrm{kw} /$, etc., pattern with the element preceding the labial-velar approximant. Nothing can be said about $/ \mathrm{y} /$, since it cannot occur in the onset position. Vowel-initial stems, which tend to appear preceded by a glottal stop $/ 2 /$ after a pause, generally pattern with voiceless and implosive stops in having $\mathrm{M}$ or $\mathrm{H}$ as their initial tone.

In order to make sense of the current distribution of tones in steminitial syllables, we have proposed the two-step scenario schematised in Figure 1 (Idiatov \& Van de Velde 2018: 185).

According to this scenario, voiced stops have acted as depressor consonants in two ways, first by lowering a following $/ \mathrm{H} /$ to $/ \mathrm{L} /$, and second by lowering a following /L/ to [extra low]. This resulted in tonogenesis: [extra low] tones were reinterpreted as $/ \mathrm{L} /$ and [low] tones as $/ \mathrm{M} /$. These two steps took place in chronological succession. The second step is familiar from Chadic languages (cf. Hyman 2013: 14). The only other language that must have gone through the first step as well that we are aware of is the Khoe language Naro (cf. Table 7 in Michaud \& Sands 2020). The internal reconstruction of an original two-tone system is confirmed by the fact that Bena-Yungur's closest relatives Mboi and Laala-Roba have a two-way tonal opposition as well, at least in our current analysis.

We have strong reasons to believe that depressor consonant induced tonogenesis only took place in stem-initial syllables. The fact that

$\begin{array}{lll}\text { Stage I } & \text { Stage II } & \text { Stage III }\end{array}$

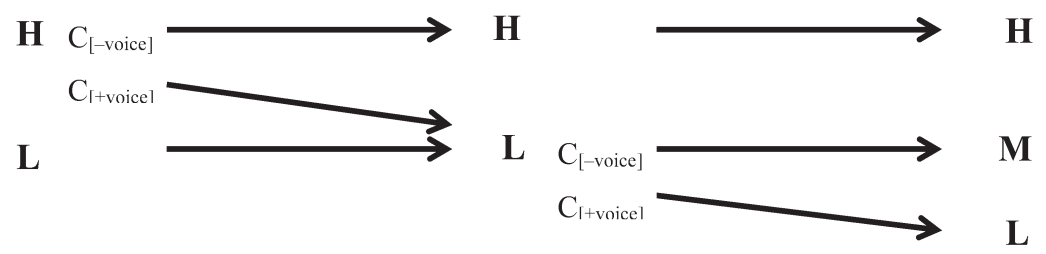

Figure 1. A scenario for the evolution of tones in stem-initial syllables in Bena-Yungur 
a three way tonal contrast exists in other positions in the stem as well is due to tone spreading. See Idiatov \& Van de Velde (2018) for examples and a more detailed discussion of the Bena-Yungur tone system.

\section{Tonal indications for the internal reconstruction of stem-initial consonants}

As we saw in $\S 2$, there are some onsets that can be followed by any of the three level tones in stem-initial position, viz. the fricatives /s/ and /f/, the labial-velar approximants $/ \mathrm{w} /$ and $/ \tilde{\mathrm{w}} /$, and the nasal-initial clusters with a velar or labial-velar stop /ng, $\widehat{\mathrm{jmgb}} /$. These must be the result of a merger of a depressor and a non-depressor consonant, a merger that must have taken place after the depressor effect of voiced stops ceased to be active. Therefore, tonal information allows us to recognise some consonants that are the result of a merger of different proto-consonants and to at least partly reconstruct the situation before the merger.

The clearest evidence for the merger of a depressor and a nondepressor consonant is provided by the fricatives $/ \mathrm{z} /$ and $/ \mathrm{s} /$, as their merger is still ongoing across Bena-Yungur dialects. Thus, the Pra dialect, our reference variety of Bena-Yungur, basically has only the voiceless fricative $/ \mathrm{s} /$, while the Guto dialect still has the voiced fricative /z/ as well. ${ }^{2}$ Whenever an /s/ is followed by a L tone in Pra, we find a $/ \mathbf{z} /$ in Guto, as illustrated in (9).

(9) GutoPra

$\begin{array}{lll}\text { zĩ̃̃ } & \text { sĩ̃ò } & \text { 'bee' } \\ \text { zòkà } & \text { sàkà } & \text { 'do, make' } \\ \text { zẫrà } & \text { sã̃rà } & \text { 'pole' } \\ \text { sámmá } & \text { sámá } & \text { 'facial hair' } \\ \text { sūmrā } & \text { sūmrā } & \text { 'navel' }\end{array}$

${ }^{2}$ The Guto data cited in the paper come from the fieldnotes kindly provided by Ulrich Kleinewillinghöfer as well as our own fieldnotes. 
The cross-dialectal data currently available to us on the other consonants in question are very limited but point in the same direction, as illustrated in (10) for an /f/ followed by a L tone in Pra that corresponds to a $/ \mathrm{v} /$ in Guto.

$\begin{array}{lll}\text { (10) GutoPra } & \\ \text { vàlàr fòlàr } & \text { 'leopard' } \\ \text { vìntì fintì } & \text { 'change, exchange' } \\ \text { fér } & \text { fér } & \text { 'mucus' } \\ \text { fàtà } & \text { fàtāo } & \text { 'two' }\end{array}$

The situation is a bit more complicated in NC clusters. We will first look at velar $/ \mathrm{gg} /$ and labial-velar $/ \widehat{\mathrm{ymgb}} /$, which differ from $/ \mathrm{mb} /$ and $/ \mathrm{nd} /$. As has been said, stem-initial / $\mathrm{gg} /$ and $/ \widetilde{\mathrm{gmgb}} /$ can be followed by any tone, so that it is highly likely that they are the result of a merger of sets of voiced and voiceless NC clusters, as schematised in (11) and (12). Contemporary Bena-Yungur does not have (labial-)velar implosives and we have no indications so far that such phonemes should be reconstructed.
(11) $\mathrm{gg} / \mathrm{H}$ or $\mathrm{M}<* \mathrm{nk}$ $\overline{\mathrm{jm}} \overline{\mathrm{gb}} / \ldots \mathrm{H}$ or $\mathrm{M}<* \overline{\mathrm{ym}} \widehat{\mathrm{kp}}$
e.g. நgārā 'chop, cut into chunks'
(12) $\underline{\text { ng } / L} \mathrm{~L}<* \mathrm{gg}$ $\overline{\mathrm{ym} g \mathrm{~g}} / \ldots \mathrm{L}<* \overline{\mathrm{ym}} \overline{\mathrm{gb}}$ ymgbállá 'jaw' ygàngà 'fold; close (door)' ymgbònrā 'mongoose'

$\mathrm{NC}$ clusters with a non-velar stop /mb, nd/ are hardly ever followed by a $\mathrm{L}$ tone. The few exceptions are of the types mentioned in $\S 2$ (borrowings, ideophones, etc.), e.g. mbàn 'cassava' borrowed from Fula. Our hypothesis for the overwhelming preponderance of $\mathrm{H}$ and $\mathrm{M}$ tones after $/ \mathrm{mb} /$ and $/ \mathrm{nd} /$ is that their voiced oral stop is the reflex of an implosive, as schematized in (13).
(13) $\mathrm{mb} / \mathrm{H}$ or $\mathrm{M}<* \mathrm{~m} 6$
nd $/$ H or $\mathrm{M}<*$ nd
e.g. mbāllā 'arm' ndóllá 'blade'


Traces of the process schematized in (13) can still be found in Bena-Yungur. For instance, the regular plural of dúu-rá 'head' is dú:-tá, but there are also some irregular alternative plural forms that show an alternation between initial $d$ and $n d$, viz. dú:-té $\sim$ dú:-tfé and ndú:-tfé. The nasal in the plural form ndú-tfé is probably a frozen class prefix.

We currently assume that reflexes of labial and alveolar NC clusters with a non-implosive stop have lost their nasal, as schematised in (14).

(14) Hypotheses on the evolution of earlier NC clusters with voiced and voiceless labial and alveolar stops:

*mp $>\mathrm{f}+\mathrm{H}$ or $\mathrm{M}$

$* \mathrm{mb}>\mathrm{v}>\mathrm{f}+\mathrm{L}$

$* \mathrm{nt}>\mathrm{t}+\mathrm{H}$ or $\mathrm{M}$

*nd $>\mathrm{d}+\mathrm{L}$

Evidence for this can be found in paradigms of person indexes for the interlocutors, i.e. first and second person forms. Due to a clusivity distinction in the first person plural, these paradigms have five forms. They are illustrated in (15) with the presentative forms 'it is X' (also used as independent personal pronominals) and in (16) with the forms fused with the copula ' $\mathrm{X}$ is...'?

(15) Presentative (independent) interlocutor person indexes 'it's X' 1sG ínâ 1PL.INCL índâ 1PL.EXCL itâ 2SG íngâ 2PL isâ

(16) Interlocutor person indexes fused with the copula ' $\mathrm{X}$ am/are...' $1 \mathrm{SG} n a^{L} \quad 1$ PL.INCL $n d a^{L} \quad 1$ PL.EXCL $t^{L}$

2SG $\quad \eta g \partial^{L} \quad 2 \mathrm{PL} \quad s \hat{a}^{L}$

${ }^{3}$ We do not consider the third person forms because they have clearly evolved out of different constructions. For example, compare the presentative forms for the interlocutors in (12) with the third person animate presentative forms, viz. the singular form áysâ áisâ 'it is him/her' and the plural form 6á:6ô 'it is them', where the personal index stems are the initial $a$ - and $b$ - respectively. 
Note that two forms have an NC cluster, two have a voiceless stop and one has a plain nasal. We have good reasons to assume that these forms are historically morphologically complex and that they all historically contain a nasal that comes from a copula that is cognate with the present-day presentative copula $\bar{\partial} n^{H}$ (also the preposition 'with') used with inanimate referents. ${ }^{4}$ The nasal of the copula was preserved in the 2sG and 1PL.INCL forms before the earlier velar non-implosive and alveolar implosive stops respectively. ${ }^{5}$ It was naturally lost before the nasal of the $1 \mathrm{sg}$ stem $n$, since there are no word-initial successions of identical consonants. Most importantly, it was also lost before the voiceless consonant of the 1PL.EXCL form without affecting it, which is evidence for the simplification rule * $n t>t$ shown in (14). ${ }^{6}$ The voiced counterpart of this simplification rule is still active today: all NC clusters with a voiced stop that belong to one morpheme tend to be simplified through the loss of their nasal component. ${ }^{7}$ When completed, this ongoing process of loss of the initial nasal in NC clusters with a voiced stop will further blur the link between a stem-initial consonant and the following tone, as it will result in voiced stops being followed by $\mathrm{H}$ and $\mathrm{M}$ tones.

${ }^{4}$ In this respect, it is noteworthy that the third person singular animate presentative person index áysâ áísâ has also been attested with a similar nasal, viz. áínsâ.

${ }^{5}$ We currently have no evidence that could indicate whether the velar stop of the 2sG pronoun was originally voiced or voiceless. Tone is of no help here, as all the members of the paradigm have a uniform tone pattern, probably shaped by their complex historical structure, and perhaps by some degree of levelling too.

${ }^{6}$ The evolution of the fricative in the $2 \mathrm{PL}$ form is somewhat complicated. Thus, although in the Guto dialect it also appears with /s/ rather than /z/, as in the presentative 2PL form isâ, suggesting an earlier voiceless fricative, in the more distantly related Livo Mboi the fricative is voiced, as in the presentative 2PL form $i$ zá, rather suggesting that originally the fricative was voiced. More comparative data are needed to decide whether the devoicing of the fricative in the 2PL form was irregular in Guto or whether it instantiates a regular sound change, such as $*_{n}>s$ in Bena-Yungur varieties and $* n s>z$ in Mboi.

${ }^{7}$ Generally, both pronunciations are possible, but sometimes consultants may doubt on the presence of the nasal in a given item or outright reject it, even when the nasal may be present in their own pronunciations. 


\section{Reconstructing the genitive construction and the lexical tone patterns of nouns}

Some nouns have two different tone schemes depending on the syntactic context in which they are used. One tone scheme, which we call Dependent Tone Scheme (DTS), is used for dependent nouns in a genitive construction, complements of a nominalized verb, and complements of the prepositions $d \bar{a}(:)^{H}$ 'in' and $\grave{a}^{M}$ 'on, at'. The other one, that we call Basic Tone Scheme (BTS), is used elsewhere, including in isolation. When the DTS is identical to the Basic Tone Scheme, as in (17)-(18) we call it DTS $_{A}$. In the examples, we show the input to the left and the surface representation after the application of tone rules to the right of the arrow.

(17) a. támá 'sheep' (BTS)

b. d dầrà támá $\rightarrow$ dầrà tàmá 'sheep skin, the skin of the sheep' $\left(\right.$ DTS $\left._{\mathrm{A}}\right)$

(18) a. dùngà 'iroko tree' (BTS)

b. līgge dùngà 'the top of the iroko tree' $\left(\mathrm{DTS}_{\mathrm{A}}\right)$

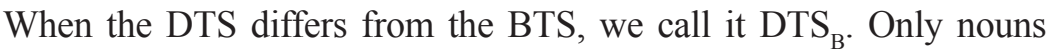
with a BTS that is entirely $L$ or entirely $H$ can have a DTS $_{B}$. Moreover, nouns with a BTS that is entirely L can only have a DTS if they are at least disyllabic. Whether such nouns have a DTS $\mathrm{A}_{\mathrm{A}}$ or a DTS $_{B}$ is lexically determined. The nouns in (17) and (18) have

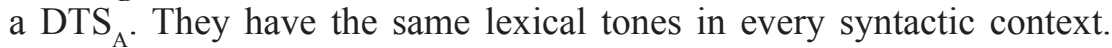

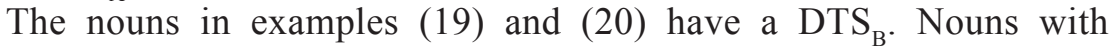
a H BTS have an entirely M DTS $_{B}(19)$. Nouns with a L BTS have a L.HL DTS

(19) a. ná: 'cow' (BTS)

b. bwàrrà nāa: 'cow dung, the dung of the cow' $\left(\mathrm{DTS}_{\mathrm{B}}\right)$

(20) a. dòbrà 'bush' (BTS)

b. tỗrā dòbrâ 'bush road, the road of the bush' $\left(\mathrm{DTS}_{\mathrm{B}}\right)$ 
Tone schemes are characteristics of words, rather than stems, in that the singular and the plural form of a noun can have different DTSs. A change in DTS can be used as a derivational tool (see Idiatov \& Van de Velde 2018: 189). There is a clear tendency for analogical levelling of the DTS towards the BTS (i.e. change from DTS $\mathrm{B}_{\mathrm{B}}$ to $\mathrm{DTS}_{\mathrm{A}}$ ). One indication for this is that speakers accept both Dependent Tone Schemes for some words (21).

(21) bìnò 'song; drumming', dă ${ }^{\mathrm{H}}$ 'in'

a. $\quad d \bar{a}^{H}$ bìnò $\rightarrow$ dā bínò 'in the song' ( DTS $\left._{\mathrm{A}}\right)$

b. $\quad d \bar{a}^{H}$ bìnô $\rightarrow d \bar{a}$ bînô 'in the song' $\left(\mathrm{DTS}_{\mathrm{B}}\right)$

Another indication can be found in nouns that have a DTS ${ }_{B}$ when they occur in compounds, clearly an archaism, and a DTS A $_{\text {elsewhere }}$ (22).

(22) nú: 'eye'

a. $\quad \delta \bar{a}$ nú: 'in the eye' $\left(\mathrm{DTS}_{\mathrm{A}}\right)$

b. áw nēer $\rightarrow$ áw né̃ 'eyeball' (lit. 'child of the eye') $\left(\mathrm{DTS}_{\mathrm{B}}\right)$

Turning to an explanation for the Dependent Tone Schemes, we can start by looking at the attested Basic Tone Schemes of disyllabic nouns. It is clear from the data in Table 1 that such nouns overwhelmingly tend to have identical tones on their first and second syllable. These data strongly suggest that the currently attested BTSs are the result of a historical merger of formerly distinguished tone patterns due to anticipatory stem-internal tone spread. The opposition between DTS $_{A}$ and $\mathrm{DTS}_{\mathrm{B}}$ must reflect an opposition in lexical tone patterns that survived only in specific syntactic contexts and was neutralised elsewhere. The relatively high number of LM nouns shown in Table 1 is due to the fact that there was no tonogenesis on non-stem-initial syllables, where $* \mathrm{~L}$ was systematically reinterpreted as $\mathrm{M}$, as well as to the fact that $\mathrm{L}$ tones do not spread onto $\mathrm{M}$ tones. It will become clear in the following discussion that the LM pattern is a reflex of *LL 
and the LL pattern a reflex of ${ }^{*} \mathrm{LH}, * \mathrm{HH}$ or $* \mathrm{HL}$, both in stems with an initial depressor consonant.

Table 1

\section{Tone patterns of disyllabic nouns}

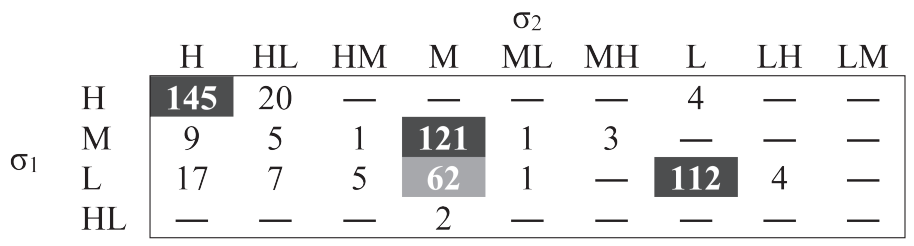

We propose that nouns with a L BTS and a DTS $_{B}$ should be reconstructed with a $* \mathrm{HL}$ tone pattern and nouns with a $\mathrm{H}$ BTS and a DTS $_{\mathrm{B}}$ with a $* \mathrm{LH}$ tone pattern. This internal reconstruction appears to be confirmed by comparative data from Laala-Roba presented in (23).

(23) Bena-Yungur Laala-Roba

$\begin{array}{lll}\text { bùt-ò } & \text { pûtú } & \text { 'ground' } \\ \text { nám-ó } & \text { nàm-ó } & \text { 'meat' } \\ \text { fátá(:) } & \text { fàtá(:) } & \text { 'horn' }\end{array}$

When more data on Bena-Yungur's closest relatives become available, we will be able to use comparative data in order to detect more cases of analogical levelling from DTS $_{B}$ to BTS, as illustrated in (24).

$$
\begin{aligned}
& \text { (24) Bena-Yungur Laala-Roba } \\
& \text { tứ: }\left(\mathrm{DTS}_{\mathrm{A}}=\mathrm{BTS}\right) \quad \text { tǘ' 'rat' }
\end{aligned}
$$

The evolution from the reconstructed lexical tone patterns of nouns to their contemporary Basic Tone Schemes, i.e. ${ }^{*} \mathrm{LH}>\mathrm{HH}$ and ${ }^{*} \mathrm{HL}$ $>$ LL, implies anticipatory tonal interactions, whereas tonal interactions in contemporary Bena-Yungur are perseveratory. There are a number of indications in contemporary Bena-Yungur that suggest that the current 
perseveratory nature of tonal interactions is an innovation. One is that the application of tone spread is optional and variable. The examples in (25) are all three acceptable. In (25a) there is no tone spread. Example (25b) illustrates by far the most common situation: tone spread one TBU to the right. In $(25 \mathrm{c})$ the $\mathrm{H}$ tone of nú: 'eye' spreads two TBUs to the right.

(25) a. nú: \# dàsè $\rightarrow$ nú: dàsè 'the eye of a bean'

b. nú: \# dàsè $\rightarrow$ nú: dásè 'the eye of a bean'

c. nú: \# dàsè $\rightarrow$ nú: dásê 'the eye of a bean'

Second, there is some dialectological evidence showing that tone spread has taken place within stems in some dialects and not or less in others. Example (26) again shows the Guto variety to be more conservative than the Pra variety.

$\begin{array}{ll}\text { (26) Guto } & \text { Pra } \\ \text { gìrángó } & \text { gìràngó 'crocodile' }\end{array}$

Both observations are compatible with the claim that rightward tone spread is innovative, which in turn is compatible with the hypothesis that tonal interactions used to be anticipatory.

Table 2 summarises the attested basic and dependent tone schemes and shows the reconstructed lexical tone patterns from which they are reflexes according to our analysis. ${ }^{8} \mathrm{~A} \mathrm{D}$ is short for depressor consonant in the syllable schemes in Table 2 and the schematic representations in (27-31). The types of nouns that have a DTS ${ }_{B}$ are boldfaced.

The evolution of the Basic Tone Schemes of Bena-Yungur nouns can be schematised as in (27) for stems with an initial depressor consonant and as in (28) for other stems. Stems with an initial voiced stop first undergo the lowering evolution schematised in Figure 1 in $\S 2$ (Stage I). If their first syllable is $\mathrm{H}$, the depressor consonant changes

${ }^{8}$ We thank Larry Hyman for this table and the suggestion of inserting it here. 
Table 2

\begin{tabular}{cccc}
\multicolumn{4}{c}{ Reflexes of reconstructed tone patterns } \\
$\begin{array}{cccc}\text { DV.CV } & & \text { BTS (27) } & \text { DTS (30) } \\
\text { *L.L } & \Rightarrow & \text { L.M } & \text { L.M } \\
\text { *H.H } & \Rightarrow & \text { L.L } & \text { L.L } \\
\text { *L.H } & \Rightarrow & \text { L.L } & \text { L.L } \\
\text { *H.L } & \Rightarrow & \text { L.L } & \text { L.HL }\end{array}$
\end{tabular}

$\begin{array}{cccc}\text { CV.CV } & & \text { BTS (28) } & \text { DTS (31) } \\ \text { *L.L } & \Rightarrow & \text { M.M } & \text { M.M } \\ \text { *H.H } & \Rightarrow & \text { H.H } & \text { H.H } \\ \text { *L.H } & \Rightarrow & \text { H.H } & \text { M.M } \\ \text { *H.L } & \Rightarrow & \text { M.M } & \text { M.M }\end{array}$

it into a LH rising tone. Nothing changes at Stage II, because anticipatory spread is blocked: $H$ tones do not spread onto a syllable with a depressor consonant as its onset. At Stage III, the depressor effect of voiced stops leads to tonogenesis. L tones in stems without a stem-initial depressor consonant are reinterpreted as M, because they are never realised extra low, while L tones in stems with a stem-initial depressor consonant realised as extra low are reinterpreted as the new $\mathrm{L}$ in a $\mathrm{H} / \mathrm{M} / \mathrm{L}$ system. For a reason explained below, we need to assume that the tonogenesis triggered by depressor consonants was restricted to stem-initial syllables. By consequence, L tones in non-stem-initial syllables were reinterpreted as $M$, except in $(27 d)$ where the tone in the non-stem-initial syllable stayed $\mathrm{L}$ due to dissimilation with the preceding $\mathrm{H}$. The evidence for this dissimilation is clearer in the evolution of DTS in stems with an initial voiced stop (30) and will be discussed there. Finally, at Stage IV, perseveratory spread of the steminitial L tone (accompanied in (27d) by the perseveratory spread of the $\mathrm{H}$ that follows it) wipes out three of the four tonal oppositions, neutralising the original four-way opposition to a two-way distinction between the minority pattern LM and the majority pattern LL. 
(27) The evolution of BTS in stems with an initial depressor consonant

$\begin{array}{llll}\begin{array}{l}\text { Stage I } \\ \text { depressor }\end{array} & \text { Stage II } & \text { Stage III } & \text { Stage IV } \\ \text { effect } & \text { spread } & & \text { H/L }>\text { H/M/L } \\ \text { H }>\text { LH } & & & \text { spread } \\ \text { spreatory }\end{array}$
a. *DV̀CV̀ DV̀CV̀
DV̀CV̀
DV̀CV̄
DV̀CV̄
b. *DV́CV́
DV̌CV́
DV̌CV́
DV̌CV́
DV̀CV̀
c. *DV̀CV́
DV̀CV́
DV̀CV́
DV̀CV́
DV̀CV̀
d. *DV́CV̀ DV̌CV̀
DV̌CV̀
DV̀CV̀

As schematised in (28), in stems whose initial consonant is not a voiced stop, anticipatory spread at Stage II neutralises the distinction between ${ }^{*} \mathrm{LL}$ and $* \mathrm{HL}$, and that between ${ }^{*} \mathrm{HH}$ and ${ }^{*} \mathrm{LH}$, but there is no depressor effect in stem-initial position and therefore no further neutralisation. Naturally, nothing changes at Stage IV as compared to Stage III since the tones of both syllables are identical. The diachronic evolutions schematized in (28) also show why we have to assume that the tonogenesis triggered by depressor consonants must be restricted to stem-initial syllables. If it were not, ${ }^{*} \mathrm{LL}$ and ${ }^{*} \mathrm{HL}$ stems would each have two possible reflexes, viz. MM and ML, depending on the characteristics of the second stem consonant (remember that $\mathrm{M}$ does not spread on a following L). However, no ML BTS is attested.

(28) The evolution of BTS in stems with an initial non-depressor consonant

$\begin{array}{lll}\begin{array}{l}\text { Stage II } \\ \text { anticipatory } \\ \text { spread }\end{array} & \text { Stage III } & \begin{array}{l}\text { Stage IV } \\ \text { perseveratory } \\ \text { spread }\end{array}\end{array}$
a. *CV̀CV̀
CV̀CV̀
$C \bar{V} C \bar{V}$
$\mathrm{C} \overline{\mathrm{V}} \overline{\mathrm{V}}$
b. *CV́CV́
CV́CV́
CV́CV́
CV́CV́
c. *CV̀CV́
CV́CV́
CV́CV́
CV́CV́
d. *CV́CV̀
CV̀CV̀
$\mathrm{CV} C \overline{\mathrm{V}}$
$\mathrm{CV} C \overline{\mathrm{V}}$ 
The two types of DTS $\mathrm{B}_{\mathrm{B}}$ found in Bena-Yungur must be due to a genitive construction that created an environment that blocks the effects of tone spreading, thereby retaining the original four-way opposition between ${ }^{*} \mathrm{HH},{ }^{*} \mathrm{LL},{ }^{*} \mathrm{HL}$ and $* \mathrm{LH}$. The morphological material responsible for this environment must have subsequently disappeared. Although trying to internally reconstruct such a construction is necessarily speculative, the exercise is worth doing, because it creates a detailed hypothesis that can later be checked against comparative data. The most straightforward reconstruction appears to be a genitive construction in which the genitive modifier is preceded and followed by a genitive marker with a $\mathrm{H}$ tone. Such a construction, similar to English a book of John's, is schematised in (29), where we represent the genitive markers by floating $\mathrm{H}$ tones, by lack of hypotheses on what their segmental shape may have been.

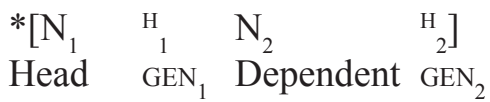

The schematic representations in (30) and (31) show the evolution of nominal tone patterns in the genitive construction, respectively for stems with an initial voiced stop and for the other stems. Stems with an initial voiced stop undergo the same changes in the genitive construction as in other syntactic environments at Stages I, II and III, described above for (27). The initial ${ }_{1}^{\mathrm{H}}$ genitive marker must have been lost before Stage IV when perseveratory tone spread became active. Otherwise, this ${ }_{1}{ }_{1}$ would have spread to the right. At Stage IV, perseveratory tone spread reduces the original four-way opposition to a three-way distinction between LM (30a), LL (30b), (30c) and L.HL (30d). The first two DTS are trivial in that they are identical to their respective BTS. However, the DTS L.HL (30d) is different from its corresponding BTS. In (30d), the final ${ }_{2}^{\mathrm{H}}$ genitive marker prevents the $\mathrm{H}$ tone of the preceding $\mathrm{HL}$ contour from spreading further to the right and delinking the final L. This final $\mathrm{L}$ itself blocks the perseveratory spread of the stem-initial L. At Stage V, the final ${ }_{2}$ genitive marker 
disappears. The original $* \mathrm{~L}$ tone in the non-stem-initial syllable was regularly reinterpreted as $M$ in (30a). However, the fact that we find a L.HL pattern rather than L.HM in (30d) suggests that the original *L stayed $\mathrm{L}$ there. We believe that this outcome is due to a dissimilatory interaction with the preceding $* \mathrm{H}$. Thus, in many languages of the region, and to an extent in Bena-Yungur too, $\mathrm{H}$ tones tend to be phonetically realised extra-high when preceding a $\mathrm{L}$ tone. Therefore, at stage III, when some of the earlier ${ }^{*} \mathrm{~L}$ tones were reinterpreted as $\mathrm{M}$, an original $* \mathrm{HL}$ pattern realised as [Extra-high + Low] was straightforwardly mapped to HL rather than HM in the new three-level $\mathrm{H} / \mathrm{M} / \mathrm{L}$ system.

(30) The evolution of DTS in stems with an initial depressor consonant

$\begin{array}{lllll}\text { Stage I } & \text { Stage II } & \text { Stage III } & \text { Stage IV } & \text { Stage V } \\ \text { depressor } & \text { anti- } & \mathrm{H} / \mathrm{L}> & \text { perse- } & \text { loss of }{ }_{2} \\ \text { effect } & \text { cipatory } & \mathrm{H} / \mathrm{M} / \mathrm{L} \text {; } & \text { veratory } & \\ \mathrm{H}>\text { LH } & \text { spread } & \text { loss of }{ }_{1} & \text { spread } & \end{array}$
a. ${ }^{* H} \mathrm{DV̀CV̀}{ }^{\mathrm{H}}$
${ }^{\mathrm{H}} \mathrm{DV̀CV}{ }^{\mathrm{H}}$
${ }^{\mathrm{H}} \mathrm{DV̀CV}{ }^{\mathrm{H}}$
DV̀C ${ }^{\mathrm{H}}$
DV̀C ${ }^{\mathrm{H}}$
DV̀CV̄
b. ${ }^{*}{ }^{\mathrm{H}} D V^{\prime} C V^{\mathrm{H}}$
${ }^{\mathrm{H}} \mathrm{DV̌CV}{ }^{\mathrm{H}}$
${ }^{\mathrm{H}} \mathrm{DV̌CV}{ }^{\mathrm{H}}$
DV̌CV́ ${ }^{\mathrm{H}}$
DV̀CV̀ ${ }^{\mathrm{H}}$
DV̀CV̀
c. ${ }^{*} \mathrm{H} D \grave{C} C V^{\mathrm{H}}$

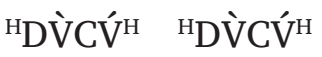
DV̀CV́ ${ }^{H}$
DV̀CV̀ ${ }^{H}$
DV̀CV̀
d. ${ }^{* H} \mathbf{D} \mathbf{V}^{\prime} \grave{V}^{\mathrm{H}}$
${ }^{\mathrm{H}} \mathrm{DV̌CV}{ }^{\mathrm{H}}$
${ }^{\mathrm{H}} \mathrm{DV̌CV̀}{ }^{\mathrm{H}}$
DV̌Cì̀
DV̀C $\hat{V}^{H}$
DV̀CV̂

In stems whose initial consonant is not a voiced stop (31), anticipatory spread at Stage II neutralises the distinction between *LL and *HL. It does not neutralise the distinction between *HH and * LH, because the initial ${ }_{1}^{\mathrm{H}}$ genitive marker blocks the anticipatory spread of the $\mathrm{H}$ tone in ${ }^{*} \mathrm{LH}$ stems (31c). At Stage III, after anticipatory spread ceases to be active, this initial ${ }_{1}^{\mathrm{H}}$ genitive marker is lost and L tones are reinterpreted as M. At Stage IV, perseveratory spread of the steminitial $\mathrm{M}$ in (31c) wipes out the final $\mathrm{H}$ and thus neutralises the distinction between the original *LL, *LH and *HL stems. 
(31) The evolution of DTS in stems with an initial non-depressor consonant

$\begin{array}{llll}\text { Stage II } & \text { Stage III } & \text { Stage IV } & \text { Stage V } \\ \text { anticipatory } & \mathrm{H} / \mathrm{L}>\mathrm{H} / \mathrm{M} / \mathrm{L} ; & \text { perseveratory } & \text { loss of }{ }_{2} \\ \text { spread } & \text { loss of }{ }_{1} & \text { spread } & \end{array}$
a. ${ }^{* \mathrm{H}} \mathrm{CV̀CV̀}{ }^{\mathrm{H}}$
${ }^{\mathrm{H}} \mathrm{CV̀CV̀}{ }^{\mathrm{H}}$
$\mathrm{C} \overline{\mathrm{V}} \overline{\mathrm{V}}^{\mathrm{H}}$
$\mathrm{C} \overline{\mathrm{V}} \overline{\mathrm{V}}^{\mathrm{H}}$
$C \bar{V} C \bar{V}$
b. ${ }^{*} \mathrm{H} C V^{\prime} C V^{\mathrm{H}}$
${ }^{\mathrm{H}} \mathrm{CV́} C V^{\mathrm{H}}$
CV́CV́ ${ }^{\mathrm{H}}$
CV́CV́ ${ }^{\mathrm{H}}$
CV́CV́
c. ${ }^{*} \mathrm{H} C \grave{C} \dot{V V}^{\mathrm{H}}$
C $\bar{C} C \hat{V}^{H}$
$\mathbf{C} \overline{\mathrm{V}} \overline{\mathrm{V}}^{\mathrm{H}}$
$\mathbf{C V} C \overline{\mathrm{V}}$
d. ${ }^{*}{ }^{\mathrm{H}} \mathrm{CV́} C \grave{V}^{\mathrm{H}}$
${ }^{\mathrm{H}} \mathrm{CV̀CV̀}{ }^{\mathrm{H}}$
$C \overline{\mathrm{V}} \overline{\mathrm{V}}^{\mathrm{H}}$
$C \overline{\mathrm{V}} \overline{\mathrm{V}}^{\mathrm{H}}$
$\mathrm{CV} C \overline{\mathrm{V}}$

As a result of the changes schematised in (27)-(31), the original four-way opposition between ${ }^{*} \mathrm{LL},{ }^{*} \mathrm{HH},{ }^{*} \mathrm{LH}$ and ${ }^{*} \mathrm{HL}$ tone patterns became reorganised in such a way that in stems with an initial voiced stop the distinction between earlier * HH and * LH became neutralised but the difference between these two etymological tone patterns and both *LL and *HL was maintained, while in stems without an initial voiced stop the distinction between earlier *LL and *HL became neutralised but the difference between these two etymological tone patterns and both $* \mathrm{LH}$ and $* \mathrm{HH}$ was maintained. Finally, the fact that nouns with an initial voiced stop with a BTS that is entirely L can only have a $\mathrm{DTS}_{\mathrm{B}}$ if they are at least disyllabic suggests that there were no monosyllabic *HL stems. Otherwise, we would have expected to find monosyllabic nouns with an initial voiced stop with a LH DTS. Alternatively, monosyllabic *HL stems with an initial voiced stop may have been so infrequent that their $\mathrm{DTS}_{\mathrm{B}}$ has been levelled to the dominant DTS $_{\mathrm{A}}$.

\section{Reconstructing the tone patterns of verbs}

There are three common tone patterns on verbs, viz. $\mathrm{H}, \mathrm{M}$ and L. As has been said, verb stems with an initial voiced stop are L and those with another stem-initial consonant are either H or M. Additionally, 
two very marginal tone patterns can be found on disyllabic verbs: L.H and H.HL. ${ }^{9}$ The absence of a L.M pattern in our current lexical database suggests that there were no verbs with an initial voiced consonant and a *L.L tone pattern. However, as we discuss below (38)-(39), some evidence from product nominalizations suggests that there must have existed at least a few verbs without an initial voiced consonant that had a *L.L pattern. Examples of each tone pattern are provided in (32).

(32) Examples of tone patterns of verbs

a. H tó: 'take', káná 'enter', kóbóró 'break by twisting'

b. M rō: 'pinch', tōmō 'do', kwēdēygēe 'bend'

c. L dà̀ 'touch', bìnì 'sing; drum'

d. L.H dònó 'descend, go down'

e. H.HL Gállâ 'braid (a rope)'

In many TAMP forms, verbs retain their lexical tone pattern. However, in the Positive Perfective and a number of other TAMP forms $H$ verbs systematically become $M$, as in (33a), and $M$ verbs systematically become $\mathrm{H}$, as in (33b). In (33), ṅ̀ ${ }^{M}$ is the first person singular subject index and $=n$ an assertive positive perfective clause-final marker. The structural representation of the verb to the left of the arrow shows its lexical tone pattern. The representations to the right of the arrow show the verbs with their Positive Perfective tone scheme.

(33) Positive Perfective

a. $\quad n \grave{M}^{M} \#$ tómó $\backslash P F V=n \rightarrow$ nà tômōn 'I did it.'

b. $\quad n \grave{\partial ̀}^{M} \# k \bar{a} n \bar{a} \backslash P F V=n \rightarrow$ nò kānán 'I entered.'

c. $n \grave{\partial}^{M} \#$ bìni $\backslash P F V=n \rightarrow$ nò bìnìn 'I sang.'

${ }^{9}$ For the moment, we have no explanation for the existence of these two marginal tone patterns. An obvious line of explanation would be to assume that these stems are morphologically complex and/or more recent borrowings whose tone patterns have not been levelled yet. 
Interestingly, we find the same tonal correspondence between verbs and product nominalisations, which typically have class markers $-r a$ and $-t a$. As illustrated in (34), product nominalisations derived from $\mathrm{H}$ verbs are $\mathrm{M}$, whereas those derived from $\mathrm{M}$ verbs are $\mathrm{H}$ (with some exceptions, to be discussed below).

(34) Some verbs and their product nominalisations
a. húrá 'forget'
hūrāi-tā 'forgetfulness'
b. káwá 'make fall; wrestle, struggle' $k \bar{a} w-r \bar{a}$ 'wrestling'
c. kāwā 'ululate'
káw-rá 'ululation'
$\left(\right.$ DTS $\left._{A \sim B}\right)$

d. kāngā 'clear bush to make a farm' kám-rá 'clearing future farmland from trees'

These facts can be accounted for if we reconstruct a $*$ L prefix for Positive Perfective verbs and for product nominalisations. The fact that this *L resulted in M suggests that this prefix had either a non-depressor initial consonant (i.e. voiceless or implosive) or no initial consonant at all. Furthermore, it is likely that this $* \mathrm{~L}$ prefix was a class prefix and that Positive Perfective and other TAMP verb forms showing the same tone alternations are reflexes of copular or auxiliary constructions with a nominalised form of the main verb. The floating $M$ tone after the first person singular subject index, shown in (33) and further illustrated in $(35 \mathrm{a}-\mathrm{e})$, and the floating $\mathrm{H}$ after the third person animate subject indexes $(35 \mathrm{f}-\mathrm{g})$, are likely reflexes of a copula. Since the copula became fused with subject person indexes, in those cases where no subject person index is used, as with the third person inanimate subjects in $(35 \mathrm{~h})$, no trace of the copula is present either.

(35) Positive Perfective paradigm of the verb kāna 'enter; start'
a. $1 \mathrm{SG}$
$n \grave{\partial}^{M} \# k \bar{a} n \bar{a} \backslash P F V=n \rightarrow$ nà kānán
'I entered.' 

b. $2 \mathrm{sG}$
$\eta g \grave{a ̀}^{M} \# k \bar{a} n \bar{a} \backslash P F V=n \rightarrow$ ygà kānán
'You (SG) entered.'
c. 1PL.INCL $n d \grave{a ̀}^{M} \#$ kānā $\backslash P F V=n \rightarrow$ ndà kānán
'We (including you) entered.'
d. 1PL.EXCL tà ${ }^{M} \# k \bar{a} n \bar{a} \backslash P F V=n \rightarrow$ tà kānán
'We (excluding you) entered.'
e. $2 P L$
sว̀ ${ }^{M}$ \# kānā $\backslash P F V=n \rightarrow$ sò kānán
'You (PL) entered.'
f. 3sG.AN $\quad \bar{a}^{H} \# k \bar{a} n \bar{a} \backslash P F V=n \rightarrow \bar{a}$ kánán
'S/he entered.'
g. 3PL.AN $\quad 6 \bar{a}^{H} \# k \bar{a} n \bar{a} \backslash P F V=n \rightarrow$ bā kánán
'They (AN) entered.'
h. 3.INAN $k \bar{a} n \bar{a} \backslash P F V=n \rightarrow$ kánán
'It/they (INAN) entered.'

The historical tone changes shown in (27)-(28) for the Basic Tone Schemes of nouns are equally valid for those of verbs. After a steminitial voiced stop, all tones become L. Elsewhere, anticipatory spread neutralises the opposition between *HL and *LL, which become M, and that between $* \mathrm{HH}$ and $* \mathrm{LH}$, which become $\mathrm{H}$. The hypothesis that some contemporary $\mathrm{H}$ and $\mathrm{M}$ tone patterns on verbs are reflexes of respectively a *LH pattern and a *HL pattern appears to be confirmed by comparative data from Laala-Roba (36).

$\begin{array}{ll}\text { (36) Bena-Yungur } & \text { Laala-Roba } \\ \text { tómó } & \text { tòmó } \\ k \bar{a} w \bar{a} & \text { káwà 'do' }\end{array}$

The tone scheme of non-L verbs in the Positive Perfective can be accounted for as in (37). The Basic Tone Scheme for each type of verb is provided for comparison in the last column. 
(37) The evolution of the Positive Perfective tone patterns in verbs with an initial non-depressor consonant

$\begin{array}{llll}\text { Stage II } & \text { Stage III } & \text { Stage IV } & \begin{array}{l}\text { Basic } \\ \text { Tone }\end{array} \\ \begin{array}{l}\text { anti- } \\ \text { cipatory } \\ \text { spread }\end{array} & \mathrm{H} / \mathrm{L}>\mathrm{H} / \mathrm{M} / \mathrm{L} & \begin{array}{l}\text { perseveratory } \\ \text { spread }\end{array} & \text { Scheme } \\ & & & \end{array}$

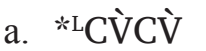
${ }^{\mathrm{L}} \mathrm{CV̀CV̀}$
${ }^{\mathrm{M}} \mathrm{C} \overline{\mathrm{V}} \overline{\mathrm{V}}$
CV̄CV̄ > CV́CV́ CV̄CV̄
b. ${ }^{* \mathrm{~L} C V ́ C V ́}$
${ }^{\mathrm{L}} \mathrm{CV́} C \mathrm{~V}$
${ }^{\mathrm{M}} \mathrm{CV́} C \mathbf{V}^{-}$
$\mathrm{C} \overline{\mathrm{V}} \overline{\mathrm{V}}$
CV́CV́
c. ${ }^{* \mathrm{~L} C V ̀ C V ́}$
${ }^{\mathrm{L}} \mathrm{CV́} C V ́$
${ }^{\mathrm{M}} \mathrm{CV} C \mathrm{~V}^{-}$
$\mathrm{C} \overline{\mathrm{V}} \overline{\mathrm{V}}$
CV́CV́

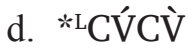
${ }^{\mathrm{L}} \mathrm{CV́CV̀}$
${ }^{\mathrm{M}} \mathrm{CV́} C \grave{\mathrm{V}}$
CV́CV́
$\mathrm{CV} C \overline{\mathrm{V}}$

In (37d), anticipatory spreading of the $\mathrm{L}$ onto the preceding $\mathrm{H}$ is blocked by the prefixed L, due to the mirror image of the rule still active today that prohibits $\mathrm{L}$ tones from spreading on a $\mathrm{H}$ if the latter is followed by a $\mathrm{M}$ or $\mathrm{L}$. The same rule later prevents the Positive Perfective prefix from spreading onto the verb stem. The regular application of the historical tone changes illustrated in (38) should have led to a split in the Positive Perfective forms of verbs whose Basic Tone Scheme is M: those with an original *LL pattern should have stayed M in the Positive Perfective (38), versus those with an original *HL pattern, which become $\mathrm{H}(37 \mathrm{~d})$. This expected split is realised in product nominalisations, as illustrated in (38)-(39).

(38) *kòdò

a. kōdō 'coagulate'

b. kwādmā 'coagulated blood' ( "kwádmá)

c. $k o ́ d o ́=n$ 'It has coagulated'

(39) *kángà

a. $\quad k \bar{a} \eta g \bar{a}$ 'clear bush to make a farm; chisel (teeth); break (bones to be able to put them in the pot); hit (forehead)'

b. kán-rá 'clearing future farmland from trees' 
c. nà kāj kám-rá=n 'I cleared future farmland from trees' (lit.: 'I cleared the clearing') ${ }^{10}$

Clearly, then, verbs with a $*$ LL tone pattern must have been rare and their Positive Perfective form has been subject to analogical levelling with the other verbs that have a M tone BTS, i.e. those with a reconstructed $*$ HL tone pattern.

The DTS of product nominalisations can also be helpful for the reconstruction of the historical tone pattern of verbs with a stem-initial voiced stop. The original tone pattern of the verb bìni 'sing; play a drum', for instance, could have been $* \mathrm{HH},{ }^{*} \mathrm{LH}$ or $* \mathrm{HL}$, as these tone patterns were neutralised to $\mathrm{L}$ after a stem-initial voiced stop and, but not *LL, as we would have expected it to result in a LM pattern, which is not attested. However, its product nominalisation bìnò 'song, drumming' can have a DTS ${ }_{\mathrm{A}}$ or a DTS $\mathrm{B}_{\mathrm{B}}$. The latter strongly suggests that the verb's historical tone pattern was ${ }^{*} \mathrm{HL}$.

Finally, note that the internal reconstruction of the tone pattern of $\mathrm{H}$ nouns of morphological classes $-r a$ and $-t a$ with a DTS $\mathrm{B}_{\mathrm{B}}$ depends on whether or not these nouns are historically action nominalisations, which can be hard to figure out if the verb from which they are historically derived no longer exists. A case in point is pám-rá, the word for a type of horn used to sound an alarm, with a DTS ${ }_{\mathrm{B}} p \bar{a} m-r \bar{a}$. If this were a reflex of a noun, its tone pattern would have to be reconstructed as $* \mathrm{LH}$. Remember that anticipatory spread of the $* \mathrm{H}$ would lead to $\mathrm{HH}$ in the BTS, whereas its blocking leads to MM in the DTS. However, if it were an action nominalisation derived from a verb *pama, the original tone pattern of that verb must have been *HL, viz. *pámà, as laid out in (39). For such cases, we will have to rely on comparative data.

${ }^{10}$ Structurally, the perfective form of kāygā is kángá (here shortened to kán because of the object following), as is made clear by the fact that the object kánrá preserves its initial $\mathrm{H}$ tone instead of the $\mathrm{M}$ tone of the preceding form $k \bar{a} \eta$ spreading on it. The $\mathrm{M}$ tone on the perfective form $k \bar{a} \eta$ itself is due to the floating $\mathrm{M}$ of the preceding positive perfective $1 \mathrm{SG}$ subject index $n \grave{\partial}^{M}$. 


\section{Summary}

Despite the ongoing devoicing of stem-initial obstruents and the historical voicing of implosives after a nasal consonant, there is still a strong correlation between stem-initial consonants and tones in BenaYungur. This has allowed us to understand that its current three-tone system is the result of a relatively recent process of tonogenesis in which $\mathrm{L}$ tones were reinterpreted as $\mathrm{M}$ in stems without a stem-initial voiced stop. The very high degree of disyllabic words with identical tones on both their syllables strongly suggests that contemporary BenaYungur tone patterns are the result of the neutralisation of a higher number of previously existing patterns due to the application of tone rules. Fortunately, the former distinctions between nominal tone patterns are still observable in some contexts where nouns have a Dependent Tone Scheme, which allows us to reconstruct the original tone patterns of nouns. In doing so, it becomes clear that the direction of tonal interactions must have shifted from anticipatory to perseveratory in the history of Bena-Yungur. It is also clear that something in the form of the genitive construction at a previous stage of Bena-Yungur must have protected the tone patterns of dependent nouns. Given our general understanding of how tone works in Bena-Yungur, we were able to propose a possible reconstruction of the genitive construction.

The internal reconstruction of lost tone patterns turned out to be possible in the verbal domain too, thanks to the tone change that takes place on verbs in the Positive Perfective and to the tone pattern of product nominalisations. Both must have had a L prefix, possibly a class prefix. It is highly likely that Positive Perfective verb forms are reflexes of a copular construction with a nominalised form of the verb.

\section{Acknowledgements}

This research is produced within the AdaGram project (http://lacan. cnrs.fr/AdaGram) funded by the "Emergence(s)" program of the City of Paris. We also gratefully acknowledge the support of the projects LC2 "Areal phenomena in Northern Sub-Saharan Africa" and GL7 "Reconstruction, genealogy, typology and grammatical description in 
the world's two biggest phyla: Niger-Congo and Austronesian" of the Labex EFL supported by a public grant overseen by the French National Research Agency (ANR) as part of the program "Investissements d'Avenir" (reference: ANR-10-LABX-0083). It contributes to the IdEx Université de Paris - ANR-18-IDEX-0001. Special thanks with respect to the present paper are due to Bitrus Andrew, our main Bena-Yungur consultant, and to Larry Hyman for useful comments. We would also like to acknowledge the anonymous referees.

\section{Abbreviations}
BTS Basic Tone Scheme
DTS $_{\mathrm{A}}$ DTS identical to BTS
D depressor consonant
DTS $_{B}$ DTS different from BTS
DTS Dependent Tone Scheme

\section{References}

Hyman, Larry M. 2013. Enlarging the scope of phonologization. In Alan C. L. Yu (ed.), Origins of sound change: Approaches to phonologization, 3-28. Oxford, UK: Oxford University Press.

Idiatov, Dmitry \& Van de Velde, Mark. 2018. The tone system of BenaYungur. In Kramer, Raija \& Kiessling, Roland (eds.), Current approaches to Adamawa and Gur languages, 171-191. Cologne: Rüdiger Köppe Verlag. (Afrika und Übersee Supplements 34.)

Idiatov, Dmitry \& Van de Velde, Mark. 2019. Bena-Mboi is Benue-Congo. Paper presented at the Adamawa Conference, Mainz, Germany.

Kleinewillinghöfer, Ulrich. 1996a. Die nordwestlichen Adamawa-Sprachen - Eine Übersicht. In Uwe Seibert (ed.), Afrikanische Sprachen zwischen Gestern und Morgen, 80-103. Köln: Rüdiger Köppe. (Frankfurter Afrikanistische Blätter 8.)

Kleinewillinghöfer, Ulrich. 1996b. Relationship between Adamawa and Gur languages: The case of Waja and Tula. Cahiers Voltaïques - Gur Papers $1,25-45$.

Michaud, Alexis \& Sands, Bonny. 2020. Tonogenesis. In Aronoff, Mark (ed.), Oxford research encyclopedia of linguistics. Oxford: Oxford University Press. https://doi.org/10.1093/acrefore/9780199384655.013.748.

Received 16.03.2020. Received in revised form 29.06.2020. Accepted 04.08.2020 